\title{
Molecular detection of EGFRvIII-positive cells in the peripheral blood of breast cancer patients
}

\author{
Henriqueta A.C. Silva ${ }^{a, *}$, Elsa Abraúl ${ }^{b}$, Dulce Raimundo ${ }^{b}$, Margarida F. Dias $^{b}$, \\ Carlos Marques $^{b}$, Carlos Guerra ${ }^{b}$, Carlos F. de Oliveira ${ }^{b}$, Fernando J. Regateiro ${ }^{a}$ \\ aDepartamento de Genética, Faculdade de Medicina, Rua Larga, 3004-504 Coimbra, Portugal \\ ${ }^{\mathrm{b}}$ Serviço de Ginecologia, Hospitais da Universidade de Coimbra, Avenida Bissaya Barreto, 300-075 Coimbra, Portugal
}

\section{A R T I C L E I N F O}

Article history:

Received 27 January 2006

Received in revised form

21 March 2006

Accepted 27 March 2006

Available online 7 September 2006

Keywords:

EGFRvIII

Breast cancer

Occult systemic disease

\begin{abstract}
A B S T R A C T
The aim of this study is to evaluate epidermal growth factor receptor variant III, EGFRvIII, a cancer specific mutant, as a possible marker for the diagnosis of breast cancer occult systemic disease. EGFRvIII mRNA was identified by an RT-nested PCR with a high sensitivity. In 102 women studied, the mutant was detected in the peripheral blood of $30 \%$ of 33 low risk, early stage patients, in $56 \%$ of 18 patients selected for neoadjuvant chemotherapy, in $63.6 \%$ of 11 patients with disseminated disease and $0 \%$ of 40 control women. In low risk, early stage patients, the presence of one or more tumour characteristics predicting recurrence such as the absence of oestrogen receptors and the presence of ERBB2 or histologic grades G2/G3 was significantly associated with EFGRvIII detection $(p<0.05)$. EGFRvIII mRNA has characteristics to be a useful marker for the diagnosis of occult systemic disease in breast cancer. Follow-up studies will evaluate its clinical value as a decision criterion for systemic therapy.
\end{abstract}

(c) 2006 Elsevier Ltd. All rights reserved.

\section{Introduction}

Breast cancer is the second leading cause of death by cancer in most Western countries. Prognosis is mainly dependent on the extension of the disease, but even with the most recent medical advances, $20-30 \%$ of patients with an apparently localised cancer will relapse. The most likely reason is an early, occult systemic dissemination.

The diagnosis of occult systemic disease may constitute a significant improvement in the treatment and prognosis of breast cancer. ${ }^{1-3}$ It may help to improve staging, especially in patients with apparently localised disease, to monitor the effectiveness of therapy and to allow a pre-clinical diagnosis of recurrences in patients already in follow-up.

PCR methodologies have been widely used in the detection of occult systemic disease in blood and bone marrow of can- cer patients. However, no suitable marker is available. Tumours are very heterogeneous and may express different mRNAs and proteins. Unfortunately, the most frequently and highly expressed markers are not cancer specific and false positives from illegitimate transcription are common in PCR-based technologies. Therefore, the search for specific markers remains an important issue to pursue.

Epidermal growth factor receptor variant III (EGFRvIII) is the most common mutant of EGFR, a receptor described in all cell types with the exception of haematopoietic cells. The mutant results from an in-frame deletion of the coding exons $2-7$, corresponding to a deletion of $801 \mathrm{bp}$ from the mRNA. ${ }^{4-6}$ The rearrangement creates a new peptide sequence at the extracellular domain, with a new amino acid, glycine, at the fusion junction. EGFRvIII may result from genomic deletion associated with EGFR amplification, or from alternative splicing. ${ }^{7-9}$

* Corresponding author: Tel.: +351 239 857713; fax: +351 239823236 .

E-mail address: hcoimbra@ci.uc.pt (H.A.C. Silva).

0959-8049/\$ - see front matter @ 2006 Elsevier Ltd. All rights reserved.

doi:10.1016/j.ejca.2006.03.033 
EGFRvIII is a ligand independent and constitutively active receptor. ${ }^{8,10}$ Its expression has been detected in a wide variety of human malignancies, including up to $50-78 \%$ of breast cancers. ${ }^{8,11-13}$ No detectable level of protein or mRNA of EGFRvIII has, however, been observed in normal adult tissues, including normal breast tissues. ${ }^{7,11,14}$ There is compelling evidence that the expression of EGFRvIII enhances tumourigenicity ${ }^{10,15,16}$ and invasiveness ${ }^{10,16,17}$ and is associated with chemo and radioresistance. ${ }^{18,19}$ Efforts are being developed to delineate cancer specific therapies having EGFRvIII as a target. ${ }^{20,21}$

In this work, EGFRvIII mRNA is evaluated as a possible marker for the diagnosis of breast cancer occult systemic disease.

\section{Materials and methods}

\subsection{Cell lines}

U87MGAEGFR, a glioblastoma cell line expressing EGFRvIII and not EGFR, was generously provided by Professor Wong from the Ludwig Institute for Cancer Research (La Jolla, San Diego); it was maintained in DMEM supplemented with $10 \%$ FBS and $200 \mu \mathrm{g} / \mathrm{ml}$ of Geneticin. CTLL-2, a lymphoblastic cell line, was a generous gift from the Histocompatibility Centre of Coimbra; cells were cultured in RPMI containing $2 \mathrm{mM}$ of L-glutamine, $10 \% \mathrm{FBS}, 10 \mathrm{U} / \mathrm{ml}$ of IL-2, $1 \mathrm{mM}$ of pyruvate and $1 \%$ penicillin-streptomycin. MDA-MB-231, a breast carcinoma cell line expressing only EGFR, was acquired from ATCC and maintained following the instructions.

Table 1 - Characteristics and results of the different groups

\begin{tabular}{|c|c|c|}
\hline $\begin{array}{l}\text { Population } \\
\text { characteristics }\end{array}$ & $\begin{array}{c}\text { Total } \\
\text { population }\end{array}$ & $\begin{array}{l}\text { EGFRvIII } \\
\text { positives }\end{array}$ \\
\hline \multicolumn{3}{|c|}{$\begin{array}{l}\text { Group A } \\
\text { (Age: mean }-63.6 \pm 11.3 \text { ) }\end{array}$} \\
\hline T2NO & 9 & 3 \\
\hline T1NO & 24 & 7 \\
\hline Total & 33 & $10(30 \%)^{a}$ \\
\hline \multicolumn{3}{|l|}{ Group B } \\
\hline IIA $^{\mathrm{b}}$ & 4 & 2 \\
\hline $\mathrm{IIB}^{\mathrm{b}}$ & 3 & 2 \\
\hline IIIA $^{b}$ & 4 & 3 \\
\hline IIIB $^{\mathrm{b}}$ & 7 & 3 \\
\hline Total & 18 & $10(56 \%)^{a}$ \\
\hline \multicolumn{3}{|l|}{ Group C (stage IV) ${ }^{\mathrm{b}}$} \\
\hline Bone metastasis & 6 & 4 \\
\hline Multiple sites ${ }^{c}$ & 4 & 3 \\
\hline Other $^{d}$ & 1 & 0 \\
\hline Total & 11 & $7(63.6 \%)^{a}$ \\
\hline Group D & \multicolumn{2}{|c|}{ (Age: mean $-41.3 \pm 11.4$ ) } \\
\hline Total & 40 & 0 \\
\hline $\begin{array}{l}\text { a } p>0.05 \text { (Yates' } \\
\text { b FIGO classificat } \\
\text { c With bone and } \\
\text { d Supra-clavicula }\end{array}$ & $\begin{array}{l}\text { astasis. } \\
\text { e metastas }\end{array}$ & \\
\hline
\end{tabular}

\subsection{Patients}

One hundred and two women divided into four groups were studied: group A, with 33 T1NOMO or T2NOMO (TMN, clinical classification) breast cancer patients, with a mean age of $63.6 \pm 11.3$ and with tumours of $3 \mathrm{~cm}$ or less of diameter, selected for curative surgery; group B with 18 high risk patients, with a mean age of $48 \pm 12.6$, selected for neoadjuvant chemotherapy; group C, with 11 patients with disseminated disease, with a mean age of $56.7 \pm 17.6$ and group $D$, a control group of 40 women free of any type of cancer with a mean age of $41.3 \pm 11.4$ (Table 1). Group B is heterogeneous and includes women from stage II A to stage III B (FIGO classification), as described in Table 1. In group A, blood was collected before surgery and in groups B and C before chemotherapy. Blood samples were processed within $1 \mathrm{~h}$ of collection. All patients had carcinomas of ductal invasive histological type, except one with an intraductal carcinoma with microinvasion and another with an invasive tumour with ductal and lobular differentiation. Patients were undergoing treatment in the Gynaecological Department of Coimbra University Hospital. Samples were consecutively collected during the period of 1 year according to patient consent and sample quality demands. Ethical approval was obtained from the Hospital Ethical Committee and all subjects gave their informed consent. Group D included University and Hospital staff, with a medical consultation during the last year, and women attending the Gynaecological Department for benign disorders.

\subsection{Patient samples}

Twenty-three tumour samples were collected from breast cancer patients submitted to surgery in the Gynaecological Department, 18 of which were from the group A patients. All these samples were of ductal invasive histological type. Samples were collected and immersed in RNAlater (Qiagen) within $1 \mathrm{~h}$ after surgery and kept at $-20^{\circ} \mathrm{C}$ or $-80^{\circ} \mathrm{C}$ until RNA extraction.

The mononuclear cell fraction of $10 \mathrm{ml}$ of EDTA treated blood was separated by gradient density centrifugation with Ficoll. A total of $5 \times 10^{6}-1 \times 10^{7}$ viable cells were used for RNA extraction.

\subsection{RNA extraction and RT-PCR}

Total RNA was extracted from cell lines with the 'Rneasy Kit' (Quiagen), and from blood and tissues with the 'Ultrasepc RNA isolation Kit' (Biotecx) according to the manufacturer's instructions. RNA was quantified spectrophotometrically at $260 \mathrm{~nm}$ and stored at $-80^{\circ} \mathrm{C}$. Synthesis of cDNA was performed with 'Omniscript kit' (Quiagen), according to the supplied protocol, using random hexamers $\left(\mathrm{Pd}(\mathrm{N})_{6}\right)$ and $5 \mu \mathrm{g}$ of total RNA.

The quality of synthesis was verified by amplifying a sequence of glyceraldehyde-3-phosphate dehydrogenase (GAPDH) cDNA (GenBank BC029618). A 171 bp sequence was amplified using primers $5^{\prime}$-TCG CCA GCC GAG CCA CAT CG3' (forward) and 5'-GAA CAT GTA AAC CAT GTA G-3' (reverse). PCR was accomplished with $2 \mu \mathrm{l}$ of cDNA, and 35 cycles with $56{ }^{\circ} \mathrm{C}$ of annealing temperature. Reaction products $(7.5 \mu \mathrm{l})$ 
were electrophoresed on a $2 \%$ agarose gel stained with ethidium bromide.

Nested PCR was designed adapting conditions already described. ${ }^{11,22}$ In both PCRs, we used Taq DNA polymerase Kit with Q-solution (Quiagen) and dUTP in substitution for dTTP. In the first round PCR, the forward primer was $5^{\prime}$-GTA TTG ATC GGG AGA GCC G-3' and the reverse primer was 5'-GTG GAG ATC GCC ACT GAT G-3'. PCR was performed with a $50 \mu$ reaction mixture containing $5-8 \mu \mathrm{l}$ of cDNA, buffer $1 \times$, Q-solution $1 \times, 200 \mu \mathrm{M}$ of dNTPs (dATP, dGTP, and dCTP), $600 \mu \mathrm{M}$ of dUTP, $0.5 \mu \mathrm{M}$ of each primer, $2.5 \mathrm{mM}$ of $\mathrm{MgCl}_{2}, 3 \mathrm{U}$ of Taq DNA polymerase and $1 \mathrm{U}$ of $\mathrm{N}$-uracyl glycosylase (UNG) heat labile. Samples were maintained for $5 \mathrm{~min}$ at $25^{\circ} \mathrm{C}$ for UNG reaction and then kept for $2 \mathrm{~min}$ at $95^{\circ} \mathrm{C}$ for UNG inactivation. PCR consisted in 40 cycles in the following conditions: $95^{\circ} \mathrm{C}$ for $45 \mathrm{~s}, 60^{\circ} \mathrm{C}$ for $45 \mathrm{~s}$ and $72{ }^{\circ} \mathrm{C}$ for $90 \mathrm{~s}$. PCR samples were then preserved at $4^{\circ} \mathrm{C}$. For the second PCR, 1$5 \mu \mathrm{l}$ of the first PCR was used. The forward primer was $5^{\prime}$ GCG ATG CGA CCC TCC GGG-3' and the reverse primer was 5'-TCC GTT ACA CAC TTT GCG-3'. Master mix composition was the same except for UNG. For amplification, one cycle of $94^{\circ} \mathrm{C}$ for $2 \mathrm{~min}$ was followed by 35 cycles of $45 \mathrm{~s}$ at $95^{\circ} \mathrm{C}$, $1 \mathrm{~min}$ at $55^{\circ} \mathrm{C}$ and $1 \mathrm{~min}$ at $72^{\circ} \mathrm{C} .8 \mu \mathrm{l}$ of cDNA and $5 \mu \mathrm{l}$ of the first PCR were used in the higher RNA dilutions in sensitivity assays $\left(1 / 10^{5}-1 / 10^{8}\right)$ and with patients and control blood samples.

For EGFRvIII, the first PCR amplifies a sequence of $352 \mathrm{bp}$ and the second PCR amplifies a sequence of 219 bp (GenBank NM_201283). For EGFR, the sequences amplified in the first and second PCR are $801 \mathrm{bp}$ longer. Reaction products $(15 \mu \mathrm{l})$ from the first and second PCRs were resolved on a $1.5 \%$ agarose gel stained with ethidium bromide.

In each set of RT-PCRs, the desired sensitivity was confirmed using dilutions $\left(1 / 10^{4}-1 / 10^{7}\right)$ of total RNA from EGFRvIII expressing cell line in total RNA from CTLL-2 cell line, as described in the sensitivity tests. Patients' samples were tested in triplicate and dilution samples in duplicate. Whenever both $1 / 10^{7}$ dilutions were negative, the sensitivity of the assay was considered to be insufficient and PCRs were repeated. At least two negative water blanks were included in each reaction. One of the negative water blanks of each reaction was used in the following procedures, from the cDNA to the second PCR, to assure the absence of contamination. In the first and second PCRs, the samples used to test the sensitivity were the last to be handled, from the higher to lower dilution, ending with the negative water blanks. Tissue processing, RNA extraction, RT-PCR assay set-up and post-PCR product analysis were performed in separate rooms to avoid contamination.

Sensitivity was established by serially diluting total RNA from U87MG $\triangle$ EGFR or from MDA-MB-231 cell lines into $5 \mu \mathrm{g}$ of total RNA extracted from CTLL-2 cell line. Serial dilutions were also done with a mixture of equal quantities of RNAs from EGFRvIII and EGFR expressing cell lines into $5 \mu \mathrm{g}$ of total RNA from CTLL-2 cell-line. Dilutions ranged from $1 / 10$ to $1 / 10^{8}$.

The specificity of the RT-PCR products was confirmed by DNA sequencing the products of the second PCR obtained from expressing cell lines and from some random selected positive blood and tumour samples. The specificity was also confirmed by applying the same RT-nested PCR assay to cells that do not express EGFRvIII: MDA-MB-231 and CTLL-2 cell lines and normal nucleated blood cells.

The protocol assures that only mRNA is amplified: for EGFR, the DNA sequences corresponding to the product amplified by the RT-PCR include several introns; for EGFRvIII, the reverse primer of the second PCR spans exons 8 and 9 junction.

\subsection{Statistical analysis}

Student's t test for continuous variables and Yates' $\chi^{2}$ test for categorical variables were used. A $p$-value $<0.05$ was considered statistically significant.

\section{Results}

As described in the last section, the sensitivity results concern RNA dilutions. For EGFRvIII marker, a sensitivity of $1 /$ $10^{4}$ was achieved in the first PCR. With nested PCR the sensitivity was of $1 / 10^{7}$. For EGFR, the first PCR had a sensitivity of $1 / 10^{3}$ and the nested PCR a sensitivity of $1 / 10^{6}$ (Fig. 1a). When both markers were simultaneously used, for higher dilutions $\left(1 / 10^{5}-1 / 10^{7}\right)$, only the deleted form was detected, achieving the same sensitivity of $1 / 10^{7}$ (Fig. 1 b). Dilutions with eight positive results out of ten were considered to be within the sensitivity threshold. For $1 / 10^{8}$ dilutions, only two in ten samples were positive, so this dilution was considered to be above the sensitivity of the assay.

Confirming the specificity of the assay and of the markers, EGFRvIII mRNA was only identified from U87MG $\triangle E G F R F$ cell line and not from MDA-MB-231 or CTLL-2 cell lines or normal leukocytes. EGFR mRNA was also identified only in MDA-MB231 cell line.

As shown in Table 1, in group D, of control women, there were no positive cases for EGFR or EGFRvIII. In the patient population, in group A, 10 were EGFRvIII positive (30\%); in group B, 10 (56\%) were EGFRvIII positive and in the metastatic group, 7 (63.6\%) were also EGFRvIII positive (Yates' $p$ value $>0.05$ ). The positive results were only seen with the nested PCR and not in the first PCR, even in blood samples from metastatic patients (Fig. 1c). Patients' samples were done in triplicate and all positive results were positive at least twice.

For group A, some risk factors of tumour recurrence were analysed between EGFRvIII positive or negative patients in peripheral blood (Table 2). There was no significant difference for age, microscopic diagnosed lymph node metastasis or tumour size. For other biological markers associated with tumour relapse, such as absence of oestrogen receptors (ER), G2-G3 histologic grade and expression of ERBB2, there was a clear higher incidence in patients EGFRvIII-positive in peripheral blood, reaching a statistically significant difference $(p<0.05)$ when the presence of one or more of these factors was considered.

To confirm the high frequency of breast cancers positive for EGFRvIII mRNA described in the literature, a group of 23 breast cancer samples, 18 of which belonging to group A of patients, was studied. In other patients from group A, it was not possible to collect tissue samples mostly due to the reduced dimensions of the tumours. Results showed that 

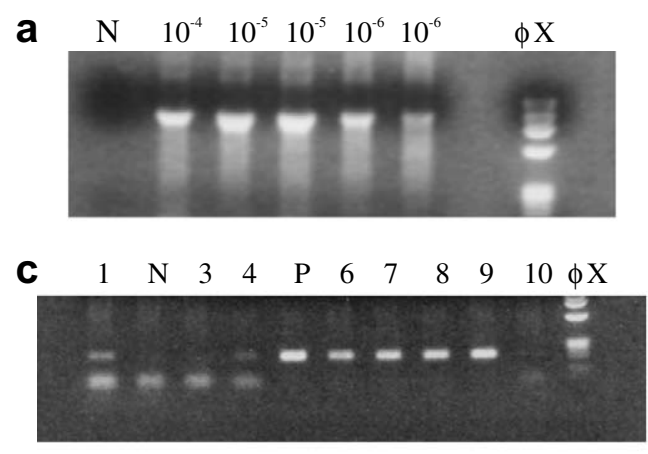
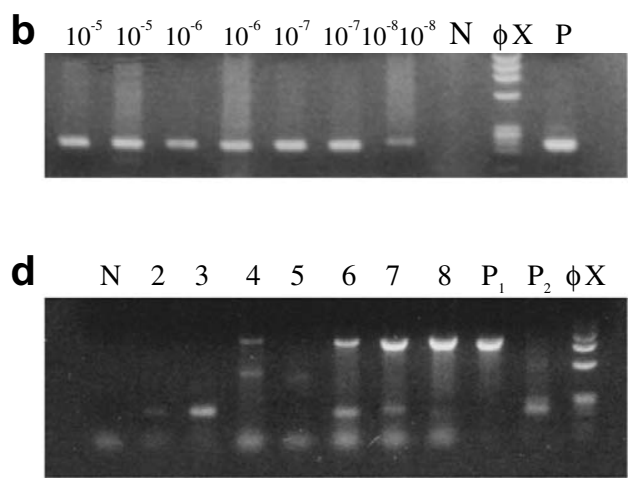

Fig. 1 - (a) Sensitivity of nested RT-PCR for EGFR: N, negative control with RNA from CTLL-2 cell line; $10^{-4}-10^{-6}-$ serial dilutions of RNA from EGFR-expressing cell line in RNA from the non-expressing cell line, CTLL-2; $\varphi \mathrm{X}-\varphi \mathrm{X}$ 174-HaeIII DNA ladder. (b) Sensitivity of nested RT-PCR for both EGFR and EGFRvIII: $10^{-5}-10^{-8}$ serial dilutions of RNAs from both EGFR and EGFRvIII-expressing cell lines in RNA from the non-expressing cell line; N, negative, water-blank control; $\varphi \mathrm{X}-\varphi \mathrm{X} 174-\mathrm{HaeIII}$ DNA ladder; P, EGFRvIII-expressing cell line. In these higher dilutions, the sequence of EGFRvIII is preferentially amplified. (c) Results of the nested RT-PCR of patients blood samples: N, negative water-blank control; lanes 3 and 10 are negative results; P, EGFRvIII expressing cell-line; $\varphi \mathrm{X}-\varphi \mathrm{X}$ 174-HaeIII DNA ladder. (d) Results of the nested RT-PCR of tumour samples: N, negative water-blank control, lanes 2-8, tumour samples; $\mathrm{P}_{1}$, EGFR expressing cell line; $\mathrm{P}_{2}$, EGFRvII expressing cell line; $\varphi \mathrm{X}-\varphi \mathrm{X}$ 174HaeIII DNA ladder. The lower band seen in (c) and (d) corresponds to excess of primers and is only apparent when amplification is absent or minimum.

Table 2 - Recurrence predictive factors in group A patients

\begin{tabular}{|c|c|c|c|c|c|c|c|c|}
\hline & \multirow[t]{2}{*}{ Age } & \multirow{2}{*}{$\begin{array}{c}\text { Tumour } \\
\text { size } \geqslant 2 \mathrm{~cm}\end{array}$} & \multirow[t]{2}{*}{$\mathrm{pN} 1$} & \multirow[t]{2}{*}{ ER negative } & \multirow{2}{*}{$\begin{array}{l}\text { Grade } \\
\text { G2-G3 }\end{array}$} & \multirow{2}{*}{$\begin{array}{c}\text { ERBB2 } \\
\text { positive }\end{array}$} & \multicolumn{2}{|c|}{ ER-/G2-G3/ERBB2+ } \\
\hline & & & & & & & $\geqslant 1^{*}$ & $\geqslant 2^{*}$ \\
\hline EGFRvIl & $58.9 \pm 11.4$ & $3 / 10(30 \%)$ & $1 / 10(10 \%)$ & $3 / 10(30 \%)$ & 9/10 (90\%) & $5 / 10(50 \%)$ & $10-10^{*}(100 \%)$ & $7 / 10(70 \%)$ \\
\hline EGFRvIII negative, $N=10$ & $64.6 \pm 11.2$ & $6 / 23(26 \%)$ & $4 / 23(17.4 \%)$ & $3 / 23(13 \%)$ & $12 / 23(52 \%)$ & 9/23 (39\%) & $13 / 23^{*}(56.5 \%)$ & 9/23 (43.55\%) \\
\hline
\end{tabular}

Statistic: Student's-t test for age and $\chi^{2}$ test for other variables; ${ }^{*} p<0.05$ for the presence of at least one of the factors; pN1, lymphatic node microscopic metastases; ER, for absence of oestrogen receptor; ERBB2+ for presence of this receptor.

$82.6 \%$ of the tumours were positive for EGFRvIII and/or EGFR, $65 \%$ being positive for EGFRvIII in nested PCR (Fig. 1D). Of the 10 group A patients with EGFRvIII identified in the peripheral blood, only three had the tumour studied: two samples were positive for the mutant and one for both the mutant and the normal transcript.

\section{Discussion}

In this paper, EGFRvIII mRNA is evaluated as a possible marker for the diagnosis of breast cancer occult systemic disease. Characterisation of tumour samples confirmed the high frequency of the mutant in breast cancer: $82.6 \%$ of the tumours were positive for EGFRvIII and/or EGFR. The RT-nested PCR assay achieved a high sensitivity of $1 / 10^{7}$ for EGFRvIII and $1 / 10^{6}$ for EGFR. The lower sensitivity for EGFR, especially when both markers were present, was probably due to the longer amplification sequence, and explains the absence of positive results. The mutant was never detected in the first PCR, even in the metastatic group of patients, confirming the need for a highly sensitive assay. The rate of EGFRvIII positive cases in patients with advanced cancer was higher than in patients with clinically localised disease, supporting the usefulness of this assay. The identification of EGFRvIII mRNA in different stages of the disease reveals that the mutant expression is stable during cancer evolution, an important feature for a tumour marker. Also, in the early stage patients, the presence of one or more tumour characteristics predicting recurrence such as the absence of oestrogen receptor (ER) and the presence of ERBB2 or histologic grades G2/G3 was significantly associated with EFGRvIII positive results in the peripheral blood $(p<0.05)$. This is particularly interesting because ERBB2 and G2 histologic grade are not always considered for adjuvant chemotherapy prescription. Though the number of patients does not allow definitive conclusions, results suggest that these two tumour phenotypic characteristics and EGFRvIII positive results in peripheral blood might help to identify those patients with T1NOM0 disease, not submitted to chemotherapy, but that still will relapse. Giving that in these early stage patients, the incidence of recurrences and of blood detection of markers of occult systemic disease is usually low, follow-up studies with larger number of patients must be accomplished to confirm the usefulness of EGFRvIII.

The lack of association between positive results in the peripheral blood and tumour size or lymph-node involvement has been described in other studies. ${ }^{1,2}$ There are evidences that distinct biological processes support lymph-node and haematic dissemination. ${ }^{23}$ 
The rates of positive results obtained with the RT-nested PCR are comparable to those described by other authors in peripheral blood, using nested $\mathrm{PCR},{ }^{2,3,24}$ real time $\mathrm{PCR}^{25}$ or recently developed antibody-based assays. ${ }^{26}$ In sensitivity tests, for practical purposes, mRNA dilutions were used, as sensitivity was tested in every PCR set of blood samples. Though the dilution of cells from expressing cell lines in blood samples is certainly a more desirable method, RNA and even cDNA dilutions have often been used. ${ }^{24,26-28}$ To avoid contamination of blood samples from cell epidermis some authors proposed to discard the first millilitres of blood, but recently, this cause of false positive results was questioned. ${ }^{25}$ Therefore, and because the EGFRvIII is a cancer specific marker, we used the whole blood sample in patients and controls.

EGFR has already been described as a good marker for the detection of circulating cancer cells in breast cancer patients, ${ }^{24,26}$ though false positives may appear because of illegitimate transcription. As a marker, EGFRvIII offers the advantage of being cancer specific, thus, reducing false positives.

A double-mutant EGFRvIII, with an additional deletion of exons 12 and 13, has rarely been described ${ }^{29}$ and may be identified by our protocol. This rare mutant has only been associated with EGFR positive tumours, so a positive result in peripheral blood would have the same meaning as an EGFRvIII positive result.

As a quantitative value for positive results may be important in prognosis evaluation, a real-time PCR with TaqMan probes for EGFRvIII and EGFR was tried, but the sensitivity achieved, of $1 / 10^{4}$, was insufficient, and, as expected by the nested-PCR results, no positive cases were detected in blood samples. In the diagnosis of occult systemic disease, real time PCR has mostly been used in patients with advanced breast cancer ${ }^{3,25}$ and few authors have described sensitivities higher than $1 / 10^{5}$ in this specific application of real-time PCR. ${ }^{25}$ Although real-time PCR is a highly reproducible quantitative PCR, contrarily to image-assisted systems, it cannot accurately quantify the number of tumour cells corresponding to the mRNA levels or evaluate the extension of the disease. ${ }^{25,28}$ For the diagnosis of occult systemic disease in solid tumours, this methodology has mainly been used to eliminate the background signal obtained from almost all markers, by establishing a cutoff point that distinguishes true positives from false positives. $3,25,28,30$

The complexity of metastasis explains its unpredictability and enhances the need for highly sensitive and specific methodologies enabling the identification of specific markers implicated in tumourigenesis and metastasis. Unfortunately, specific markers, like EGFRvIII or mammaglobin ${ }^{31}$, demand assays with sensitivities not easily achieved.

Although the expression of EGFRvIII has been described in $50-72 \%$ of breast cancers by many authors, ${ }^{8,11-13}$ using different methodologies (PCR, immunohistochemistry and Western blotting), including laser capture technology, ${ }^{13}$ recently the absence of EGFRVIII expression in breast cancer paraffinembedded samples was reported. ${ }^{32}$ These conflicting results may be explained by differences in sensitivity assays and in sample management. So that archived tissues accurately reflect mRNA expression before fixation, some factors have to be optimised, namely time from surgical excision to fixa- tion. ${ }^{33}$ This is critical when concerning breast cancer samples, because of the pathological procedures necessary for staging. Less abundant mRNAs may be lost. It was also proven that the process of formalin fixation and paraffin embedding differentially affects the ability to analyse different mRNA species even from the same gene. ${ }^{33}$

Despite the frequent expression of EGFRvIII in human epithelial cancers, it has been difficult to detect EGFRvIII expression in most human cancer cell lines. ${ }^{18,32}$ The common explanation, either a growth disadvantage in vitro or a positive selection for EGFRvIII in vivo, was recently confirmed by two different groups. ${ }^{21,34}$ A similar phenomenon has been verified with other genes. ${ }^{35}$

In the diagnosis of breast cancer occult systemic disease, it is important to search for a panel of specific cancer markers to create personalised protocols. EGFRvIII has characteristics to be an interesting candidate, though it requires a highly sensitive methodology. It has the advantage of being a cancer exclusive mutation associated with tumourigenicity and metastasis and of being a good target for specific therapy. In early stage disease, the detection of EGFRvIII in peripheral blood is associated with indicators of tumour aggressiveness. Larger sample studies and long term observation will evaluate its clinical value as a decision criterion for systemic therapy.

\section{Conflict of interest statement}

None declared.

\section{Acknowledgements}

The authors thank Foundation for Science and Technology (FCT) who supported this work and all the personnel of the Gynaecological Department of Coimbra University Hospital for their collaboration. We are also indebted to Professor Gareth Evans (St. Mary's Hospital, Manchester) for his suggestions and critical review of this manuscript.

\section{R E F E R E N C E S}

1. Braun S, Pantel K, Muller P, et al. Cytokeratin-positive cells in the bone marrow and survival of patients with stage I, II or III breast cancer. N Engl J Med 2000;342:525-33.

2. Stathopoulou A, Vlachonikolis D, Mavroudis M, et al. Molecular detection of cytokeratin-19-positive cells in the peripheral blood of patients with operable breast cancer: evaluation of their prognostic significance. J Clin Oncol 2002;20:3404-12.

3. Weigelt B, Bosma AJ, Hart AAM, Rodenhuis S, van't Veer LJ. Marker genes for circulating tumour cells predict survival in metastasized breast cancer patients. $\mathrm{Br} \mathrm{J}$ Cancer 2003;88:1091-4.

4. Bigner SH, Humphrey PA, Wong AJ, et al. Characterization of the epidermal growth factor receptor in human glioma cell lines and xenografts. Cancer Res 1990;50:8017-22.

5. Humphrey PA, Wong AJ, Volgestein B, et al. Anti-synthetic peptide antibody reacting at the fusion junction of deletion- 
mutant epidermal growth factor receptors in human glioblastoma. Proc Natl Acad Sci USA 1990;87:4207-11.

6. Sugawa N, Ekstrand AJ, James CD, Collins VP. Identical splicing of aberrant epidermal growth factor receptor transcripts from amplified rearranged genes in human glioblastomas. Proc Natl Acad Sci USA 1990;87:8602-6.

7. Moscatello DK, Holgado-Madruga M, Goodwin AK, et al. Frequent expression of a mutant epidermal growth factor receptor in multiple human tumours. Cancer Res 1995;55:5536-9.

8. Moscatello DK, Montgomery RB, Sundareshan P, McDanel H, Wong MY, Wong AJ. Transformation and altered signal transduction by a naturally occurring mutant EGF receptor. Oncogene 1996;13:85-96.

9. Wong AJ, Ruppert JM, Bigner SH, et al. Structural alterations of the epidermal growth factor receptor gene in human gliomas. Proc Natl Acad Sci USA 1992;89:2965-9.

10. Batra SK, Castelino-Prabhu S, Wikstrand CJ, et al. Epidermal growth factor ligand-independent, unregulated, celltransforming potential of a naturally occurring human mutant EGFRvIII gene. Cell Growth Differ 1995;6:1251-9.

11. Wikstrand CJ, Hale LP, Batra SK, et al. Monoclonal antibodies against EGFRvIII are tumour specific and react with breast and lung carcinomas and malignant gliomas. Cancer Res 1995;55:3140-8.

12. Gong XG, Moscatello DK, Wong AJ, Lippman ME, Tang CK. Proc Am Assoc Cancer Res 2000;41:2907. 456.

13. Ge H, Gong X, Tang CK. Evidence of high incidence of EGFRvIII expression and co-expression with EGFR in human invasive breast cancer by laser capture microdissection and immunohistochemical analysis. Int J Cancer 2002;98:357-61.

14. Garcia de Palazzo IE, Adams GP, Sundareshan P, et al. Expression of mutated epidermal growth factor receptor by non-small cell lung carcinomas. Cancer Res 1993;53:3217-20.

15. Nagane M, Coufal F, Lin H, Bogler O, Cavenee WK, Huang HJ. A common mutant epidermal growth factor receptor confers enhanced tumorigenicity on human glioblastoma cells by increasing proliferation and reducing apoptosis. Cancer Res 1996;56:5079-86.

16. Tang CK, Gong X, Moscatello DK, Wong AJ, Lippman ME. Epidermal growth factor receptor vIII enhances tumoriginecity in human breast cancer. Cancer Res 2000;60:3081-7.

17. Pedersen MW, Tkach V, Pedersen N, Berezin V, Poulsen HS. Expression of a naturally occurring constitutively active variant of the epidermal growth factor receptor in mouse fibroblasts increases motility. Int J Cancer 2004;20:643-53.

18. Montgomery RB, Guzman J, O'Rourke DM, Stahl WL. Expression of oncogenic epidermal growth factor receptor family kinases induces paclitaxel resistance and alters betatubulin isotype expression. J Biol Chem 2000;275:17358-63.

19. Lammering G, Hewit TH, Valerie $\mathrm{K}$, et al. EGFRvIII-mediated radioresistance through a strong cytoprotective response. Oncogene 2003;28:5545-53.

20. Kuan CT, Wikstrand CJ, Bigner DD. EGFR mutant receptor vIII as a molecular target in cancer therapy. Endo-Related Cancer 2001;8:83-96.
21. Luo X, Gong X, Tang CK. Suppression of EGFRvIII-mediated proliferation and tumorigenesis of breast cancer cells by ribozyme. Int J Cancer 2003;104:716-21.

22. Worm K, Dabbagh P, Schwechheimer K. Reverse transcriptase polymerase chain reaction as a reliable method to detect epidermal growth factor receptor exon 2-7 gene deletion in human gliobastomas. Hum Pathol 1999;30:222-7.

23. Huang E, Cheng SH, Dressman H, et al. Gene expression predictors of breast cancer outcomes. Lancet 2003;361:1590-6.

24. De Luca A, Pignata S, Casamassini A, et al. Detection of circulating tumour cells in carcinoma patients by a novel epidermal growth factor receptor reverse transcription-PCR assay. Clin Cancer Res 2000;6:1439-44.

25. Aerts J, Wynendaele W, Paridaens R, et al. A real-time quantitative reverse transcriptase polymerase chain reaction (RT-PCR) to detect breast carcinoma cells in peripheral blood. Ann Onc 2001;12:39-46.

26. Leitzel K, Lieu B, Curley E, et al. Detection of cancer patients using reverse transcription-polymerase chain reaction for epidermal growth factor receptor. Clin Cancer Res 1998;4:3037-43.

27. Bostick PJ, Chatterjee S, Chi DD, et al. Limitations of specific reverse-transcriptase polymerase chain reaction markers in the detection of metastases in the lymph nodes and blood of breast cancer patients. J Clin Oncol 1998;16:2632-40.

28. Bosma AJ, Weigelt B, Lambrechts AC, et al. Detection of circulating breast tumour cells by differential expression of markers genes. Clin Cancer Res 2002;8:1871-7.

29. Callaghan T, Antczack M, Flickinger T, Raines M, Myers M, Kung HJ. A complete description of the EGF-receptor exon structure: implication in oncogenic activation and domain evolution. Oncogene 1993;8:2939-48.

30. Slade MJ, Smith BM, Sinnett HD, Cross NCP, Coombes RC. Quantitative polymerase chain reaction for the detection of micrometastases in patients with breast cancer. J Clin Oncol 1999;17:870-9.

31. Cerveira N, Torres L, Rocha $P$, et al. Highly sensitive detection of the MGB1 transcript (mammaglobin) in the peripheral blood of breast cancer patients. Int $J$ Cancer 2004;108:592-5.

32. Rae JM, Scheys JO, Clark KM, Chadwick RB, Kiefer MC, Lippman ME. EGFR and EGFRvIII expression in primary breast cancer and cell lines. Breast Cancer Res Treat 2004;87:87-95.

33. Godfrey TE, Kim S-H, Chavira M, et al. Quantitative mRNA expression analysis from formalin-fixed, paraffin-embedded tissues using 5' nuclease quantitative reverse transcriptionpolymerase chain reaction. J Mol Diag 2000;2:84-91.

34. Pandita A, Aldape KD, Zadeh G, Guha A, James CD. Contrasting in vivo and in vitro fates of glioblastoma cell subpopulations with amplified EGFR. Genes Chromosomes \& Cancer 2004;39:29-36.

35. Sasaki T, Hankins GR, Helm GA. Comparison of gene expression profiles between frozen original meningiomas and primary cultures of the meningiomas by GeneChip. Neurosurgery 2003;52:892-9. 